\title{
Cold storage of conifer seedlings: An update from the British Columbia perspective
}

\author{
by E.L. Camm ${ }^{1,2}$, D.C. Goetze ${ }^{1}$, S.N. Silim ${ }^{2}$ and D.P. Lavender ${ }^{2}$
}

\begin{abstract}
In both the temperate and boreal regions of North America and Scandinavia, conifer seedlings are routinely cold stored for several months in order to accommodate the schedules of nurseries and tree planters alike. It is critical to the success of the practice to understand the biology of the seedlings, in particular the influence of environmental factors such as temperature and light on their yearly cycle. Since Hocking and Nyland's important 1971 review, research has characterized the effects of different methodoligical parameters of the cold storage process (lift date, storage temperature, moisture, etc.) on a number of physiological aspects of the trees (root growth potential, photosynthesis, stress resistance). This has led to better guidelines and awareness on the manipulation of seedlings for cold storage. This article will review some of that research, concentrating on the Western experience.
\end{abstract}

Key words: conifer seedlings, nurseries, cold storage, physiology, stress resistance

\section{Introduction}

Stress resistance is generally lowest in conifer seedlings in a natural field habitat at times when the seedlings are actively growing. Conversely, plants are most resistant to a number of stresses (frost, mechanical, darkness, etc.) during those periods when growth is minimal or zero. In seedling nurseries, the cycle is interrupted by fall or winter lifting and subsequent cold storage where the plants receive none of the clues of the natural environment.

Cold storage of conifer seedlings is widely practiced in the temperate and boreal regions of North America, as well as in Scandinavia. Successful management of this technique involves an understanding of the ways in which plants respond to changes in temperature and photoperiod in yearly cycles of growth and dormancy. Operationally in nurseries, moisture stress or lengthening nights in midsummer stimulate the formation of resting buds (Lavender 1990). Early fall conditions (mild temperature and long nights) promote rest, or true dormancy, in the apical meristem and initiate cold hardiness in the entire plant. Late fall condition (low temperatures and very long nights) terminate rest and maximize cold hardiness. In principle, seedlings put into cold storage at this stage and protected from naturally occurring environmental variations over the course of winter should remain cold hardy and able to break bud upon receipt of the appropriate heat sum after planting the following spring. In practice, cold storage is used primarily to facilitate nursery and planting schedules, and growers sometimes work against, rather than with, the biology of the tree.

This article reviews some of the research on methods and physiological effects of cold storage in the last 20 years, concen-

${ }^{1}$ Department of Botany and ${ }^{2}$ Department of Forest Science, University of British Columbia, Vancouver, BC, Canada V6T 1 Z4.
Dans les régions tempérés et boréal d'amerique du nord et de scandinavie, les semies de conifères sont souvent entreposés au froid pendent quelques mois afin de concilier les horaires des pépinières et des planteurs. Il est fondamentale au succès de cette méthode de bien connaître la biologie des semies, en particulier, l'influence de facteurs environmentaux, tel la température et la lumière. Depuis la revue de littérature de Hocking et Nyland (1971), plusieurs recherches ont été entreprises sur les effets de différent paramètres contrôlant l'entreposage au froid (date d'entreposage, température d'entreposage, condition hydrique des semies, etc.) sur la physiologie des arbres (potentiel de croissance racinaire, photosynthèse, la résistance au stress). Ces études ont permis une meilleure compréhension, ainsi qu'une amélieration du protocole, sur le traitement des semies lors d'entreposage au froid. Cette article rend compte des recherche récentes sur ce sujet avec une emphase particulier sur la région de l'ouest canadien.

Mots clés: semies de conifères, pépinières, entreposage au froid, physiologie, résistance au stress

trating on the Western experience. It revisits and updates a number of research areas Hocking and Nyland (1971) identified as important at the time, along with their presentation of a useful and detailed summary of a range of storage scenarios and the effects of various practices upon subsequent seedling survival and growth.

\section{Predictors of Lifting Date: Components of Stress Resistance}

Both experimental and commercial experience have shown that the date of storage initiation is critical to the subsequent outplanting success. Lifting date was a major factor of survival for numerous reforestation species, including ponderosa pine (Pinus ponderosa Dougl. ex Lawr.) (Stone and Schubert 1959), Douglas fir (Pseudotsuga menziesii (Mirb.) Franco) (Lavender 1964; Lavender and Wareing 1972), western hemlock (Tsuga heterophylla (Raf.) Sarg.) (Nelson and Lavender 1979), black spruce (Picea mariana (Mill.) B.S.P.) and jack pine (Pinus banksiana Lamb.) (Lavender and Silim 1992). Seedlings that were lifted in early fall (September or October) had consistently less vigor than those lifted in or later than the middle of November. Early fall lifted trees also had poorer root growth initiation and lower stomatal conductance at the end of storage periods than trees lifted in November (Omi et al. 1991). Consequently, early-lifted trees also had significantly lower survival when planted, regardless of planting locale (field, greenhouses or nurseries). Seedlings lifted in early fall probably had not reached a sufficient physiological status to endure cold storage. Re-enforcing this point are studies showing that induced early bud set by artificially shortened photoperiod promoted increased vigor and survival among early-lifted seedlings (Lavender and Wareing 1972; Nelson and Lavender 1979; Lavender and Silim 1992). Obviously, seedlings must be physiologically ready for the conditions of cold storage. 
A major concern is how to reliably gauge the optimal time for initiation of cold storage. The question has been raised whether the components of stress resistance could be used to estimate seedlings' tolerance to cold dark storage and as a guide lift date. Hocking and Nyland (1971) concluded "that for overwinter storage, lifting should be delayed as long as possible". Data from more recent studies (Lavender and Wareing 1972; Garber and Mexal 1980; Mullin 1980; Sutton 1984; Ritchie et al. 1985; Ritchie 1986; Racey 1987; Lavender and Silim 1992) confirmed their conclusion. The fact that the date of lifting affected seedling performance after cold storage suggested that tolerance depended on the stage of growth during which the seedlings were lifted. Burr (1990) pointed out that drought stress (Lavender 1985), low temperature stress (Glerum 1985), mechanical stress (Tabbush 1986) and root exposure stress (Hermann 1967) affected the tree in different ways. The result of these processes is that the seedling achieves maximum stress resistance in late fall and early winter.

Components of stress resistance have been used to predict the time period for lifting for cold storage. In British Columbia and Ontario, cold hardiness has been suggested as a guide for timing the initiation of cold storage (Burdette and Simpson 1984; Colombo et al. 1984). The former researchers showed that if seedlings for storage were not lifted until they were coldhardy to $-18^{\circ} \mathrm{C}$, their root growth capacity after 6 months of cold $\left(-2^{\circ} \mathrm{C}\right)$ storage was equivalent to the pre-storage value. For this reason, seedlings cold hardy to $-18^{\circ} \mathrm{C}$ are considered ready for storage in B.C., and by this standard, white spruce seedlings may be considered ready for storage in early October. However, this suggestion is contradicted by the evidence for the benefits of delayed lifting. The disparity may be in methodology since root growth capacity measured at elevated root temperatures does not necessarily reflect rooting ability at lower field soil temperatures (Husted and Lavender 1989; Camm and Harper 1991).

Measurement of chlorophyll fluorescence from the foliage of species such as white and Engelmann spruce (Picea engelmanni (Parry) Engelm.) might be useful in determining the winter lifting period (Hawkins and Binder 1990). In fact, fluorescence measurements have demonstrated a seasonal inactivation of the photosynthetic apparatus in the fall that occurs concomitantly with bud set and progression toward dormancy (Hawkins and Binde 1990; Vidaver et al. 1991). However, in white spruce, photosynthetic inactivation was generally complete by late October (which correlated with cold hardiness to $-18^{\circ} \mathrm{C}$ ) (Vidaver et al. 1989). Thus, while inactivation of photosynthesis parallels the early stages of general stress resistance development in spruce, it likely occurs too early to act as an indicator of maximum tolerance to cold storage.

An obvious contributor to stress resistance and overwinter storage success is sufficient metabolic and nutrient reserves. As a natural preparation for winter, reserve carbohydrates, vegetative storage proteins (VSP) and other nitrogen reserves (eg. arginine) accumulate during early fall in seedlings of many species. The first predominantly take the form of sugars and starch, although lipids are considered to be important reserves as well (Glerum 1980), and accumulate to varying degrees in different parts of the plant. In Sitka spruce (Picea sitchensis (Bong.) Carr) and Douglas fir, needles were found to contain the most carbohydrate reserves at the time of storage, stems less and roots the least (Cannell et al. 1990), although Ritchie
(1982) found reserves in Douglas fir stems to be less than in roots. Furthermore, accumulation of a VSP in white spruce seedling buds, stems and roots of seedlings was investigated as a potential indicator of lifting suitability (Roberts et al. 1991).

These reserves are exceptionally important because, while the dark and cold conditions of storage preclude any photosynthesis, other metabolic processes (in particular, respiration) continue to function. Fortunately, these same conditions also cause respiration to slow down considerably. The rate of respiration during cold storage has been estimated at $0.025-0.053 \mathrm{mg}$ $\mathrm{CO}_{2} \cdot \mathrm{g}^{-1} \bullet \mathrm{h}^{-1}$ (Ritchie 1982; Cannell et al. 1990), but both studies found that even these low respiration rates resulted in depletion of reserve carbohydrates during the storage period. Respiration rates declined in Douglas fir from a whole plant approximate average of $150-195 \mathrm{mg}^{\circ} \mathrm{g}^{-1}$ dry weight to about $40-85 \mathrm{mg}^{\circ-1} \mathrm{dry}^{-1}$ weight, as respiratory loss is temperature dependent. Ritchie (1987) found that seedlings stored at $-2^{\circ} \mathrm{C}$ had about $2.5 \mathrm{mg}^{-1} \mathrm{~g}^{-1}$ more reserve carbohydrate than ones stored at $+2^{\circ} \mathrm{C}$. This reflects the enzymatic nature of the process. Significantly, despite general agreement that both amount and types of storage carbohydrates present during storage must affect field performance, critical compounds have not been identified for the various stages during storage and subsequent planting. Accordingly, measurement of storage carbohydrates is presently unlikely to help predict the ability of seedlings to resist and survive storage stress.

Another component of general stress resistance is the ability to withstand mechanical impact. Lavender $(1985,1991)$ demonstrated that this resistance to mechanical stress increases in seedlings in autumn, as judged by growth after planting the next spring. Further studies showed that seedlings lifted in early fall were more susceptible to mechanical stress than those lifted later (Lavender 1985, 1991; Silim and Lavender 1992; Lavender and Silim 1992) or after storage (Stjernberg 1992). Seedling cold hardiness and mechanical stress resistance develop at different rates and times of onset during the fall which suggests that they are mediated by different physiological mechanisms (Silim and Lavender 1992). Mechanical stress resistance has currently no predictive value for assessing individual seedling lots as it cannot be evaluated prior to lifting. However, another property temporally correlated to mechanical stress resistance may be of more predictive value. One such possibility may be mitotic index. Some workers have suggested using the incidence of dividing cells in apical meristems as indicators of seedling physiology, because rapidly dividing cells in growing tissue frequently show low resistance to many kinds of stress. Hawkins and Binder (1990) reviewed several reports which suggested a correlation between mitotic index in meristems and cold hardiness. Lavender (1989) reported that the period during which no mitotic figures were present in the apical meristems of Douglas fir seedlings, i.e. December through February, was similar to the period of maximum stress resistance for this species. However, during this pericd of maximum stress resistance and shoot meristem quiescence, cell division may still be occurring in the roots (McKay and Mason 1991). Therefore, mechanical stress resistance of the whole seedling is not a property inherent from its interphase cells. The relationship between shoot meristem activity and mechanical stress resistance deserves further study and may have a future role as a predictor of mechanical stress resistance. As mentioned, a number of biological processes occur at different rates in seedlings during the fall. Recognizing 
this, Lavender $(1985,1991)$ postulated an annual "stress resistance cycle" which peaked (for Canadian latitudes) during the period from early December until early March, based upon annual patterns of increasing and decreasing resistance to a variety of stresses. Processes developing earlier in the autumn, such as cold hardiness, may be considered necessary but not sufficient. Full resistance to winter stresses may not occur until later in the season with the acquisition of resistance to mechanical stress. However, because of the multifactorial nature of stress resistance, exclusive reliance on a single factor, possibly one developing too early in the season, is unlikely to give a complete prediction of lift date. Thus, the original recommendation of Hocking and Nyland (1971) still stands: that to minimize deleterious effects on seedling vigour, "lifting should be delayed as long as possible". The growers' dilemma, that of later lift dates increasing the risk of stock freezing in containers, is just as much a problem now as in 1971 .

\section{Duration of Storage}

Seedling storage in areas of mild climate such as the southern US and the Pacific coast of the US and Canada may be as short as a few days and rarely exceeds three months. In contrast, storage in areas of continental or boreal climates may extend for as long as seven or eight months. There are few reports which truly reflect the effects of storage duration on seedling vigour, because often storage duration and date of initiation of storage effects are confounded.

In a natural setting, the chilling requirement of dormancy release will be met during winter through continued exposure to temperatures below $6^{\circ} \mathrm{C}$ (Ritchie 1987) and rest will give way to quiescence. Cold storage, usually at or below $2^{\circ} \mathrm{C}$, also fulfills the chilling requirement and dormancy will also be released over the storage period. In fact, in the lift/store regime, dormancy was released with time exponentially before lifting but placement in cold storage resulted in a significant delay in the rate of dormancy release in Douglas fir (Ritchie 1984), in lodgepole pine (Pinus contorta Dougl.) and interior spruce (Picea glauca $\times$ engelmanni) (Ritchie et al. 1985). Furthermore, as dormancy declined with storage time of spruce lifted after rest had developed, a concomitant increase in root growth potential (RGP) was observed. Analogous results were observed by Burr et al. (1989) in the same two species and also with ponderosa pine.

Unfortunately, the relationship between bud dormancy and RGP during storage may not be as straight forward as this, in particular after long storage durations. The increasing ability to grow roots is simply a physiological expression of increasing readiness to initiate development given appropriate conditions. However, observations that RGP declined sharply with prolonged storage ( $>6$ months [Ritchie 1982] $>22$ weeks [Camm and Harper 1991]) suggest that a direct relationship to declining dormancy is unlikely. The dropping RGP may indicate the seedling has shifted priority emphasis from the roots to shoot growth. Thus, extended cold storage could well be detrimental to trees by disturbing their natural sequence of next-season growth initiation events. Overall, these different physiological processes cannot be separated from one another and a moderate period of cold storage does not significantly disrupt these endogenous mechanisms of seedling development. This latter conclusion assumes that seedlings put into cold storage were lifted at an appropriate time. Hermann (1967), Ritchie $e t$ al. (1985) or Dewalt and Feret (1988) demonstrated that effects of storage duration may be more pronounced for seedlings lifted prior to development of maximal stress resistance or after such resistance has begun to decline, than for midwinter lifted seedlings. Clearly, the deleterious effect of extended storage is more serious for early lifted material. Not only do seedlings lifted in December and planted in May have the benefit of shorter storage time, they also profit from a higher level of stress resistance.

\section{Storage Temperature}

Hocking and Nyland (1971) noted that satisfactory storage temperatures ranged from $+3^{\circ} \mathrm{C}$ to $-6^{\circ} \mathrm{C}$. Higher temperatures increased incidence of mold (Lavender and Wareing 1972) and losses of respiratory substrate, while temperatures lower than $-5^{\circ} \mathrm{C}$ have been shown to be damaging to a range of species (Cram and Lindquist 1981; Williston 1974; Mullin and Parker 1976; van den Driessche 1977). Most seedling storage facilities maintain temperatures 1-2 degrees above freezing or 2-4 degrees below freezing. The latter regimes are termed "frozen storage", although such temperatures are not sufficiently low to freeze seedling sap - the freezing is confined to the rooting medium surrounding the container grown seedling root systems. In British Columbia, all twelve coniferous species grown commercially for reforestation projects may be stored successfully at $-2^{\circ} \mathrm{C}$ (van Eerden and Gates 1990). Freezer storage of coniferous seedlings is widely employed in the northwestern United States (Omi et al. 1991) and in Canada (Mullin and Parker 1976; Cram and Lundquist 1981; Ritchie et al. 1985; Simpson 1990). The rationale for utilizing temperatures below freezing is twofold: (a) seedling respiration rate is reduced and hence, less carbohydrate reserve is lost during the storage period, and (b) such temperatures inhibit the growth of molds. However, frozen stock is generally subjected to slow thawing prior to planting, during which time the increased respiratory rate may utilize much of the storage reserves conserved by the lower temperature (see Chomba 1992 for discussion), and molds may develop during the thaw period (Nyland 1974). Further, accidental exposure of thawed stock to warm temperatures results in rapid loss of cold hardiness (Lavender and Silim, unpublished results) and even loss of viability (Binder and Fielder 1988). The above considerations advocate storage at $0^{\circ} \mathrm{C}$ as a means to maintain the benefits of low temperature storage while minimizing the problems involved with thawing.

\section{Seedling Moisture During Storage}

Hocking and Nyland (1971) surveyed reports from nurseries in Canada and the United States with respect to humidity maintained during storage and found that the majority maintained humidity above $85 \%$. However, then, seedlings were commonly stored with the roots packed in media and the shoots exposed. More recent practices in seedling storage have included enclosing the entire plant in a plastic, moisture retaining film. This is presumably to preserve favorable water relations in stored stock and avoid desiccation stress. This also carries a risk of infection by pathogenic molds, but this is minimized by low temperature (Lavender and Camm 1992). Although it is precisely during dormancy stage that conifers are most resistant to water stress and can tolerate substantial drying of both the roots and shoots without appreciable injury (Ritchie 1987), with the post-planting 
transition to growth, this tolerance dramatically decreases and trees become more sensitive to water stress.

Studies investigating seedling moisture stress during storage are somewhat contradictory and the topic remains controversial. Low seedling water potential at the time of storage was highly correlated with reduced seedling vigour after subsequent outplanting (Daniels 1978), but Rose et al. (1992) found little effect of moisture treatment on dormancy release and growth response after storage of up to 209 days. Cold stored Sitka spruce seedlings, that were desiccated during storage (to $\Psi_{\mathrm{w}}^{\text {plant }}<-2.5$ $\mathrm{MPa}$ ), showed negligible effects on dormancy and overall carbohydrate content, but dramatically reduced RGP (Deans et al. 1990). In combination with rough handling, drying reduced RGP by $98 \%$ although, seemingly contradictory, the outplanted seedlings had an initial field survival of over 95\%. Tabbush (1986) also found desiccated $\left(\Psi_{\mathrm{w}}\right.$ plant $\left.<-2.0 \mathrm{MPa}\right)$ Sitka spruce suffered no effect on either survival or height growth. Survival in the former study did decrease with time, with only $77 \%$ of the desiccated trees and $27 \%$ of desiccated and rough handled trees living three years.

Severe desiccation reduces moisture content of fine roots in particular (Coutts 1981; Insley and Buckley 1985). This makes the recovery of overall plant water potential difficult and therefore, inhibits root growth significantly (Coutts 1981). Furthermore, decreased shoot moisture content has been correlated positively with needle damage suffered by black spruce (Picea mariana (Mill.) B.S.P.) during cold storage (Colombo 1990). Once field planted, these injuries may not immediately affect performance, but quality is compromised in a seedling planted with an effectively smaller root system and damaged needles, although under some conditions the deficit may be overcome. Nonetheless, it is important to minimize any potential risk by ensuring seedlings destined for storage are not moisture stressed.

\section{Light During Storage}

The lack of a daily photoperiod during the cold, dark storage commonly employed by forest nurseries is an obvious departure from the natural environment which seedlings experience during their dormant period. Yet, this inconsistency has stimulated only a minimum of research by workers concerned with vigour of planting stock. The first apparent reference to possible photoperiod effects during storage is that of Deffenbacher and Wright (1954) who noted that Douglas-fir seedlings experienced increased survival after receiving a daily photoperiod over the course of a storage period initiated in fall and terminated a year later. This effect was attributed to a reduction in the incidence of pathogenic fungi.

More recently, Lavender (1989) reviewed work conducted with Douglas-fir and western hemlock lifted and stored during the fall months and concluded that a daily photoperiod during storage improved the subsequent survival and growth of these species. Similar treatment of seedlings lifted and stored in January did not improve survival, but did accelerate initiation of bud growth. Douglas-fir seedlings lifted in January and maintained at a constant $4^{\circ} \mathrm{C}$ temperature with a daily photoperiod demonstrated normal shoot growth in June and July, while those kept in darkness at the same temperature produced only greatly delayed, abnormal shoot activity. A similar study by Johnson (1982) demonstrated that winter lifted loblolly pine (Pinus taeda L.) seedlings exposed to a daily photoperiod during storage had accelerated bud elongation after outplanting in either a greenhouse or in the field. Finally, in fall lifted conifers of five boreal species (white spruce, black spruce, Engelmann spruce, lodgepole pine, jack pine), a significant increase in survival and postplanting growth was observed in seedlings exposed to daily photoperiods in storage, relative to dark stored control groups (Lavender and Silim 1992). Additionally, unpublished data from this work and other studies suggested that cold hardiness could actually increase in seedlings experiencing a daily photoperiod in storage.

All of the foregoing research was conducted using light levels below the compensation point of photosynthesis. Accordingly, the effects of the photoperiod are seemingly mediated through the phytochrome system and may involve the plant growth regulators involved in circadian rhythms. The generally greater positive effects of daily photoperiods of seedlings lifted in the fall is consistent with the low stress resistance reported for plants lifted at this time. Thus, operationally, it may be more useful to combine early lifting with light during storage, while later lifted stock can be effectively dark stored, at least until further research investigates this area more thoroughly.

\section{Conclusion}

Hocking and Nyland (1971) recommended that lifting for cold storage should be delayed as long as possible and recognized a number of areas requiring the attention and investigation of growers and researchers. While research is needed (especially in water relations), the last 20 years has seen the characterization of the cold storage effects on others parameters (RGP, photosynthesis, etc). This has led to a better understanding of how seedlings can be manipulated in storage and to what guidelines should be established.

Overall, the effects of cold storage on conifer physiology remain a cost/benefit compromise. While the technique is likely somewhat stressful to the plants, it is far from drastically damaging for any but fall lifted seedlings. In fact, past and current work on biological changes in seedlings during fall and winter is leading to a better understanding of the nature of stress resistance. From this work, stresses causing deleterious effects in fall-lifted stock have far less negative outcomes in winterlifted ones. Thus, twenty years of investigation confirm the original conclusion of Hocking and Nyland (1971): growers are well advised to delay lifting as late as practically possible. If difficult operationally, one potential scenario that would allow incorporating sufficient delay would be holding seedlings in unheated greenhouses. Alternatively, exposing seedlings with well formed buds to $8 \mathrm{~h}$ daily photoperiods in August was shown to be effective in reducing the negative effects of cold, dark storage initiated in mid-fall (Lavender and Silim 1992).

Ultimately, cold storage allows trees to be planted on sites that are environmentally ready to receive them, increasing their potential for long-term survival. The appropriate use of cold storage can result in higher quality planting stock and contribute to maximizing any potential improvements in field performance likely to result from the combination of better cutting control, site preparation, planting techniques and long-term monitoring of the re-forested site.

\section{References}

Binder, W.D. and P. Fielder. 1988. The effects of elevated post-storage temperatures on the physiology and survival of white spruce seedlings. 
In: T.D. Landis (ed.) Proc. of the Combined Meetings of the Western For. Nursery Assoc., Vernon, BC.

Burdette, A.N. and D.G. Simpson. 1984. Lifting, grading, packaging and storing. In: M.L. Duryea and T.D. Landis (eds.) Forest Nursery Manual. Production of Bareroot Seedlings. pp. 227-234. Martinus Nijhoff/W. Junk, The Hague. 395 p.

Burr, K.E., R.W. Tinus, S.J. Wallner and R.M. King. 1989. Relationships among cold hardiness, root growth potential and bud dormancy in three conifers. Tree Physiol. 5: 291-306.

Burr, K.E. 1990. The target seedling concepts: Bud dormancy and cold-hardiness. In: R. Rose, S.J. Campbell and T.D. Landis (eds.). Target Seedling Symposium, Proceedings of the combined Meeting of the Western Forest Nursery Associations. pp. 79-90. 13-17 August 1990, Roseburg, OR. U.S.D.A. Gen. Tech. Rep. R.M. 200. Rocky Mt. For. and Rge. Exp. Sta., Fort Collins, CO. 285 p.

Camm, E.L. and G.J. Harper. 1991. Temporal variations in cold sensitivity of root growth in cold-stored white spruce seedlings. Tree Physiol. 2: 425-431.

Cannell, M.G.R., P.M. Tabbush, J.D. Deans, M.K. Hollingsworth, L.J. Sheppard, J.J. Philipson and M.B. Murray. 1990. Sitka spruce and Douglas fir seedlings in the nursery and in cold storage: root growth potential, carbohydrate content, dormancy, frost hardiness and mitotic index. Forestry 63: 9-27.

Chomba, B. 1992. Carbon dioxide enrichment and the role of carbohydrates in root growth potential of cold stored Engelmann spruce (Picea engelmannii (Parry)) seedlings. M. Sc. (Forestry) Thesis. University of British Columbia, Vancouver, BC. 120 p.

Colombo, S.J. 1990. Bud dormancy status, frost hardiness, shoot moisture content and readiness of black spruce container seedlings for frozen storage. J. Amer. Soc. Hort. Sci. 115: 302-307.

Colombo, S.J., D.P. Webb, C. Glerum. 1984. Frost hardiness testing: An operational manual for use with extended greenhouse culture. Ont. Min. Nat. Res. Forest Res. Rep. No. 110.14 p.

Coutts, M.P. 1981. Effects of root or shoot exposure before planting on the water relations, growth and survival of Sitka spruce. Can. J. For. Res. 11: 703-709.

Cram, W.H. and C.H. Lundquist. 1981. Overwintering and spring storage of pine and spruce seedlings. For. Chronicle 57: 162-164.

Daniels, T.G. 1978. The effects of winter plant moisture stress on survival and growth of 2-0 Douglas-fir seedlings. Unpublished M.Sc. thesis. Oregon St. Univ., Corvallis, OR. 86 p.

Deans, J.D., C. Lundberg, P.M. Tabbush, M.G.R. Cannell, L.J. Sheppard and M.B. Murray. 1990. The influence of desiccation, rough handling and cold storage on the quality and establishment of Sitka spruce planting stock. Forestry 63: 129-141.

Deffenbacher, F.W. and E. Wright. 1954. Refrigerated storage of conifer seedlings in the Pacific Northwest. J. Forestry 52: 936.

Dewalt, L.E. and P.P. Feret. 1988. Changes in lobolly pine seedling root growth potential, dry weight and dormancy during cold storage. For. Sci. 34: 41-54.

Garber, M.P. and J.G. Mexal. 1980. Lift and storage practices: Their impact on successful establishment of southern pine plantation. N. Zealand J. For. Sci. 10: 72-82.

Glerum, C. 1980. Food sinks and food reserves of trees in temperate climates. N. Zealand J. For. Sci. 10: 176-185.

Glerum, C. 1985. Frost hardiness of coniferous seedlings: principles and applications. In: M.L. Duryea (ed.) Evaluating seedling quality: Principles and predictive abilities of major tests. pp. 107-123. For. Res. Lab. Oregon State Univ., Corvallis, OR. 143 p.

Hawkins, C.D.B. and W.D. Binder. 1990. State of the art seedling stock quality tests based on seedling physiology. In: R. Rose, S.J. Campbell and T.D. Landis (eds). Target Seedling Symposium, Proceedings of the combined Meeting of the Western Forest Nursery Associations. pp. 91-122. 13-17 August 1990, Roseburg, OR. U.S.D.A. Gen. Tech. Rep. R.M. 200. Rocky Mt. For. and Rge. Exp. Sta., Fort Collins, CO. $285 \mathrm{p}$.

Hermann, R.K. 1967. Seasonal variation in the sensitivity of
Douglas-fir seedlings to exposure of roots. For. Sci. 13: 140-149. Hocking, D. and R.D. Nyland. 1971. Cold storage of coniferous seedlings. A review. AFRI Res. Rep. No. 6. College of For., SUNY at Syracuse. $70 \mathrm{p}$.

Husted, L. and D.P. Lavender. 1989. Effect of soil temperature upon the root growth and mycorrhizal formation of white spruce (Picea glauca (Moench) Voss) seedlings grown in controlled environments. Annales des Sciences Forestières. 46 suppl. 7503-753S.

Insley, H. and G.P. Buckley. 1985. The influence of desiccation and root pruning on the survival and growth of broadleaved seedlings. J. Hort. Sci. 60: 377-387.

Johnson, J.D. 1982. The effects of photoperiod during cold storage on the survival and growth of loblolly pine seedlings. In: E.P. Jones Jr. (ed.) Proceedings of the Second Biennial Southern Silvicultural Research Conference. pp. 401-408. 4-5 November 1982, Atlanta, GA. USDA For. Serv., Southeastern For. Exp. Sta. Gen. Tech. Rep. SE24

Lavender, D.P. 1964. Date of lifting for survival of Douglas-fir seedlings. Oregon State University For. Res. Lab., Corvallis, OR. Research Note 49. $20 \mathrm{p}$.

Lavender, D.P. 1985. Bud Dormancy In: M.L. Duryea (ed.) Evaluating seedling quality: Principles and predictive abilities of major tests. pp. 7-15. For. Res. Lab., Oregon State Univ., Corvallis, OR. 143 p. Lavender, D.P. 1989. Characterization and manipulation of the physiological quality of planting stock. In: J. Worrall, J. Loo-Dinkins and D.T. Lester (eds). Proceedings, 10th North American Forest Biology Workshop. pp. 32-57. UBC, Vancouver, BC. 364 p.

Lavender, D.P. 1990. Physiological principles of regeneration. In: D.P. Lavender, R. Parish, C. Johnson, G. Montgomery, A. Vyse, R.A. Willes and D. Winston (eds). Regenerating British Columbia's Forests. pp. 30-44. Univ. of Brit. Col. Press, Vancouver, BC. 372 p. Lavender, D.P. 1991. Measuring phenology and dormancy. In: J.P. Lassoie and T. M. Hinckley (eds.) Techniques and approaches in forest tree ecophysiology. pp. 403-422. CRC Press, Boca Raton, FL. 599 p. Lavender, D.P. and E.L. Camm. 1992. Cold storage of coniferous planting stock in British Columbia. In: J. Gillham (ed). Proceedings of the 1991 Ontario Tree Seedling Growers Association Workshop. Kirkland Lake, ON. Ont. Min. Nat. Res., Timmins, ON.

Lavender, D.P. and S.N. Silim. 1992. The relationship of pre-harvest and storage photoperiods to the vigour of seedlings of some boreal coniferous species. In: J. Gillham (ed). Proceedings of the 1991 Ontario Tree Seedling Growers Association Workshop. Kirkland Lake, ON. Ont. Min. Nat. Res., Timmins, ON.

Lavender, D.P. and P.F. Wareing. 1972. Effects of daylength and chilling on the responses of Douglas-fir (Pseudotsuga menziesii (Mirb) Franco) seedlings to root damage and storage. N. Phytol. 71: 1055-1071.

McKay, H.M. and W.L. Mason. 1991. Physiological indicators of tolerance to cold storage in Sitka spruce and Douglas fir seedlings. Can. J. For. Res. 21: 890-901.

Mullin, R.E. 1980. Water dipping and frozen overwinter storage of red and white pine. Tree Planters' Notes. 31: 25-28.

Mullin, R.E. and J.D. Parker. 1976. Provisional guidelines for fall lifting for frozen overwintering storage of nursery stock. For. Chronicle 62: 1-4.

Nelson, E.A. and D.P. Lavender. 1979. The chilling requirement of western hemlock seedlings. For. Sci. 25: 485-490.

Nyland, R.D. 1974. Subfreezing temperatures control storage molding. Research Note No. 11, Appl. For. Res. Inst., College of Environmental Sci. and For., Syracuse, NY. 3 p.

Omi, S.K., B. Yoder and R. Rose. 1991. Fall lifting and long-term freezer storage of ponderosa pine seedlings: Effects on post-storage leaf water potential, stomatal conductance, and root growth potential. Tree Physiol. 8: 315-325.

Racey, G.D. 1987. Cold temperature conditioning of conifer seedlings prior to frozen overwinter storage. For. Res. Rep. No. 118. Ont. Min. Nat. Res. 7 p. 
Ritchie, G.A. 1982. Carbohydrate reserves and root growth potential in Douglas fir seedlings before and after cold storage. Can. J. For. Res. 12: 905-912.

Ritchie, G.A. 1984. Effects of freezer storage on bud dormancy release in Douglas fir seedlings. Can. J. For. Res. 14: 186-190.

Ritchie, G.A. 1986. Relationship among bud dormancy status, cold hardiness and stress resistance in 2+0 Douglas-fir. New For. 1: 2942.

Ritchie, G.A. 1987. Some effects of cold storage on seedling physiology. Tree Planter's Notes 38: 11-15.

Ritchie, G.A., J.R. Roden and N. Kleyn. 1985. Physiological quality of lodgepole pine and interior spruce seedlings: Effects of lift date and duration of freezer storage. Can. J. For. Res. 15: 636-645. Roberts, D., P. Toivonen and S.M. McInnis. 1991. Discrete proteins associated with overwintering of interior spruce and Douglas fir seedlings. Can. J. Bot. 69: 437-441.

Rose, R., S.K. Omi, B. Court and K. Yakimchuk. 1992. Dormancy release and growth responses of $3+0$ bare-root white spruce (Picea glauca) seedlings subjected to moisture stress before freezer storage. Can. J. For. Res. 2: 132-137.

Silim, S.N. and D.P. Lavender. 1992. Relationship between cold hardiness, stress resistance and bud dormancy in spruce (Picea glauca (Moench) Voss) Seedlings. In: F.P. Donnelly and H. Lussenburg (eds.) pp. 9-14. Proceedings of the 1991 Forest Nursery Association of British Columbia Meeting. 153 p.

Simpson, D.G. 1990. Frost hardiness, root growth capacity and field performance relationships in interior spruce, lodgepole pine, Douglas fir and western hemlock seedlings. Can. J. For. Res. 20: 566-572.

Stjernberg, E.I. 1992. Stock handling from the nursery to the plant- ing site: An investigation into rough handling and its biological effects. FERIC, Western Div., Vancouver, BC. 46 p.

Stone, E.C. and G.H. Schubert. 1959. Ponderosa pine planting stock. Calif. Agricul. 3: 11-12.

Sutton, R.F. 1984. Bareroot planting season options. For. Chronicle 60: 328-335.

Tabbush, P.M. 1986. Rough handling, soil temperatures and root development in outplanted Sitka spruce and Douglas-fir. Can. J. For. Res. 16: $1385-1388$.

van den Driessche, R. 1977. Survival of coastal and interior Douglas fir seedlings after storage at different temperatures, and effectiveness of cold storage in satisfying chilling requirements. Can. J. For. Res. 7: 125-131.

van Eerden, E. and J.W. Gates. 1990. Seedling production and processing: Container. In: D.P. Lavender, R. Parish, C. Johnson, G. Montgomery, A. Vyse, R.A. Willes and D. Winston (eds). Regenerating British Columbia's Forests. pp. 226-234. Univ. of Brit. Col. Press, Vancouver, BC. 372 p.

Vidaver, W.E., W. Binder, R.C. Brooke, G.R. Lister and P.M.A. Toivonen. 1989. Assessment of photosynthetic activity of nursery grown Picea glauca (Moench.) Voss seedlings using an integrating fluorometer to monitor variable chlorophyll fluorescence. Can. J. For. Res. 19: 14781482.

Vidaver, W.E., G.R. Lister, R.C. Brooke and W.D. Binder. 1991. A manual for the use of variable chlorophyll fluorescence in the assessment of the ecophysiology of conifer seedlings. FRDA Report 163. $60 \mathrm{p}$.

Williston, H.L. 1974. Storage of southern pine seedlings: A review. Tree Planter's Notes Fall: 1-3. 